\title{
Implementation of Authentic Assessment Curriculum 2013 of Mandarin Language in SMK Prapanca 2 Surabaya
}

\author{
Novia K. Nisaa ${ }^{1, *}$ Miftachul Amri ${ }^{1}$ Syamsul Sodiq ${ }^{2}$ \\ 1,2 Education of Language and Literature, Universitas Negeri Surabaya, Indonesia \\ *Corresponding author.Email novia.20003@mhs.unesa.ac.id
}

\begin{abstract}
The purpose of this study was to find out how the preparation of authentic assessment instruments at SMK Prapanca 2 Surabaya, the implementation of authentic assessments of Chinese subjects at SMK Prapanca 2 Surabaya, and the use of authentic assessment results of Chinese subjects at SMK Prapanca 2 Surabaya. The research method used in this study is a descriptive qualitative approach. The research was conducted at SMK Prapanca 2 Surabaya in class XII. The subject in this study was a teacher of Mandarin class XII. The results of this study are that the teacher has implemented authentic assessment well but is constrained by time and infrastructure. The results of this authentic assessment can make it easier for teachers to map students' character so that teachers can easily determine what method is suitable for use.
\end{abstract}

Keywords: Authentic assessment, 2013 curriculum, Chinese language.

\section{INTRODUCTION}

The development of Human Energy Resources (HR) in Indonesia is part of Indonesia's national development process and goals. Therefore, the government has always sought the quality of learning in Indonesia. Learning quality control controls the quality of human resources (human energy sources) located in the system. To identify the quality control, data is needed regarding the characteristics of children, the use of teachers, and whether the school supports the implementation of learning programs so that the results can be achieved optimally.

In the 2013 curriculum, authentic evaluation is applied, which will seriously emphasize teachers to more thoroughly examine students in terms of ability, attention, and achievement. According to Sani [1], authentic evaluation focuses students on demonstrating the skills and competencies needed to deal with cases and situations found in the real world. On the other hand, in Permendikbud RI No. 66 of 2013 Authentic evaluation is an evaluation that is tried comprehensively to take into account aspects of behavior, knowledge, skills ranging from inputs (inputs), processes to educational outputs. Authentic evaluations are natural, as they are, not under pressure.

From some of the interpretations above, it can be concluded that authentic evaluation is an evaluation that is tried on students comprehensively both in terms of aspects of knowledge, aspects of behavior, and expertise starting from input, process to output by observing the totality of activities that students actually try. The implementation of authentic evaluation in the context of the 2013 curriculum has been explicitly stated in Permendikbud No. 66 of 2013, overriding the evaluation standard which explains that the Learning Evaluation Standard is viewed as a criterion overriding the mechanisms, procedures, and instruments for evaluating student learning outcomes.

According to Rusman [2], the types of authentic evaluation are: 1) Behavioral Evaluation: evaluation of behavioral aspects is tried through observation, selfevaluation, the evaluation between friends and daily. 2) Knowledge evaluation, knowledge evaluation includes written tests in the form of explanations or essays to require students to be able to remember, master, organize, practice, analyze, synthesize, evaluate, and so on the modules that have been studied. After that, the second is an oral test where this oral test is in the form of problems given orally so that students respond to these problems verbally and bring up the courage to students. Oral tests are usually submitted during the teaching and learning process. Then the last is an assignment, it is an evaluation that is tried by educators which can take the form of homework both individually and in groups according to the characteristics of the task. 3) Expertise Evaluation, 
Skill evaluation usually has two basic characteristics, namely: (1) test participants are asked to show or demonstrate their ability to make a product or participate in an activity (process / action), and (2) the product of the results applications also need to be assessed. Usually, the evaluation of expertise is tried by observing the implementation of a task or checking the products produced by students.

There is also the virtue of authentic evaluation according to Muller [3] (in Prastowo), who says that the virtue of authentic evaluation includes occurring as follows: 1) The use of authentic evaluation allows direct measurement of student performance as an achievement of the competencies being learned. 2) Authentic evaluation provides opportunities for students to construct their learning outcomes. With authentic evaluations, students are asked to construct what they have learned in a concrete environment. Thus, the learner will select and focus the answers based on their knowledge and the analysis of the situation that is tried so that the answers are relevant and meaningful. 3) Authentic evaluation allows the integration of teaching, learning, and evaluation activities into an integrated activity package. 4) Authentic evaluation provides opportunities for students to display their learning outcomes, their performance with a method that is considered very good.

The difficulty in authentic evaluation is described (In Sani) if, the main difficulty encountered in the evaluation of behavior is in terms of scoring. Usually there are three main sources of error in scoring behavior evaluation, as follows: 1.) Problems in the instruments, instruments, and scoring guidelines used unclear will make it difficult for appraisers to use. 2.) Procedural problems, if the procedures used in evaluating behavior are not well structured, the scoring results will be carried away. 3.) The problem of bias in the scorer tends to be difficult in terms of eliminating the problem of personal ties with the assessed students so that there is a "personal bias".

Sutan et al. [4] investigated the management of authentic evaluation of the 2013 curriculum for authentic subjects in high school. They reported that from the analysis carried out in his research, authentic evaluation could standardize students' thinking skills, share data with parents, and revise education implementation plans. The similarity in this research is that they both carry out an authentic evaluation analysis on teachers of certain subjects but it is different in this research. This time the research is on Mandarin teachers in SMK

Rifka et al. [5] studied the analysis of the authentic application of the 2013 curriculum by chemistry teachers at Banda Aceh State High School. They reported that the analysis results carried out in his research show that all chemistry teachers have carried out authentic evaluations. Teachers have integrated authentic evaluation during the educational process, which includes three aspects of competence: behavior, knowledge, and skills. However, from the results of questionnaires and interviews, it is known that the implementation of authentic evaluation has not been carried out perfectly by some chemistry teachers at SMA Negeri Banda Aceh. Aspects that limit the application of authentic evaluation are (1) the lack of training accompanied by some teachers. Some teachers have not had time to explore training, (2) the modules that were informed during the training did not focus on discussing authentic evaluations but explained all aspects of the 2013 curriculum, (3) the large number of students that must be assessed individually. People, (4) limited time available to carry out evaluations, and (5) existing facilities and infrastructure have not been utilized optimally. The similarity in this research is that they both carry out authentic evaluation analyses for certain subject teachers but are different in this research. This research is the management of authentic evaluations of the 2013 curriculum for Chinese subjects at SMK Prapanca 2 Surabaya.

Based on previous research, the researcher aims to analyze the management of the authentic evaluation of the 2013 curriculum for Chinese subjects at SMK Prapanca 2 Surabaya. The formulation of the problem in this study is how to arrange authentic evaluation instruments at SMK Prapanca 2 Surabaya, apply authentic evaluation of Chinese subjects at SMK Prapanca 2 Surabaya, and use the results of authentic evaluation of Chinese subjects. at the SMK Prapanca 2 Surabaya. Thus, this research is very meaningful to try because this research aims to describe the arrangement of authentic evaluation instruments at SMK Prapanca 2 Surabaya, describe the application of authentic evaluation of Chinese subjects in SMK Prapanca 2 Surabaya, and utilization of the results of the authentic evaluation of Chinese subjects at the SMK Prapanca 2 Surabaya. With the objectives to be achieved in this research, we can indirectly have a reflection of how the arrangement of authentic evaluation instruments at the SMK Prapanca 2 Surabaya, the application of authentic evaluation of Mandarin subjects in the SMK Prapanca 2 Surabaya, and the use of authentic evaluation results of Chinese subjects at SMK Prapanca 2 Surabaya

\section{METHODS}

The research method used in this study is a descriptive qualitative approach. According to Boghdan and Taylor [6] qualitative research is a procedure that produces descriptive data in the form of speech or writing. The data collected is descriptive data based on the phenomenon of the case to be studied. In this reseach, the data obtained from the results of the implementation of authentic assessment and teacher difficulties in implementing authentic assessment. The research was conducted at SMK Prapanca 2 Surabaya in class XII. This research was conducted to describe the facts and 
characteristics of the objects/subjects studied, namely the management of authentic assessments of Mandarin subjects at SMK Prapanca 2 Surabaya. The subjects in this study were teachers of Mandarin class XII.

\section{RESULTS AND DISCUSSION}

\subsection{Arrangement of authentic assessment instruments at SMK Prapanca 2 Surabaya}

The arrangement of authentic assessment instruments at SMK Prpanca 2 Surabaya is carried out at the beginning of the semester, determining the KKM value and making RPP. The steps of the Chinese teacher in compiling an authentic assessment instrument in the 2013 curriculum are. Determine what aspects will be assessed, including cognitive aspects (knowledge), affective aspects (attitudes), motor aspects (skills). The aim is to determine the characteristics and criteria of each aspect of the assessment.

In the next stage, the Mandarin teacher of the SMK Prapanca 2 Surabaya formulates the evaluation objectives of each aspect of the evaluation with the hope that the objectives of the evaluation are clear and wellplanned so that the evaluation instrument to be made can actually be used to map the condition of students who are actually.

After formulating the assessment objectives of the Mandarin teacher at SMK Prapanca 2 Surabaya, they formulated indicators based on the basic competencies contained in the syllabus. Thus the teacher can sort out and ensure the evaluation method to be used in an evaluation. The method used must match the module to be taught because otherwise it will not be appropriately assessed, so the purpose of an evaluation will not be achieved.

An instrument can be used if it has benchmarks or criteria for completeness that can interpret the results of student evaluations. This is because an instrument can be used to calculate if it has a completeness criterion. It is because the criteria for completeness become a dimension, whether the evaluation results are successful or not, the Chinese teacher at the SMK Prapanca 2 Surabaya made the minimum completeness criteria that had been included in the RPP.

In compiling the instrument, the teacher needs to identify the objectives of an evaluation to be tried. The Mandarin teacher of the SMK Prapanca 2 Surabaya has carried out the steps in structuring the evaluation instrument by determining the aspects to be studied, formulating a goal, formulating indicators that are following the basic competencies contained in the syllabus, and making criteria minimum completeness as a benchmark for the assessment results.

\subsection{Implementation of authentic assessment of Chinese subjects at SMK Prapanca 2 Surabaya}

This data shows how the implementation of an authentic assessment and the difficulty factors in implementing an authentic assessment of Chinese teachers at SMK Prapanca 2 Surabaya. The data obtained are then described.

Based on Table 1 item 1. a, it is known that the mandarin teacher makes an authentic assessment instrument. The instruments that the Chinese teacher has made are adjusted to the indicators to be achieved. Many of the instruments made were not used in the assessment process. This instrument is only contained in the Learning Implementation Plan (RPP) and is in accordance with the indicators to be achieved by students. The assessment technique used is in the form of observations and journals wherein the teacher makes an observation sheet adapted to the material to be taught. Observation sheets have been prepared in each lesson plan so that during teaching and learning activities, the teacher observes and fills out the observation sheet. While in the journal assessment the teacher observes the behavior of students both inside and outside the classroom

In assessing the skills, the teacher used performance and portfolio assessments. In assessing the performance, he made an assessment rubic. Then the teacher informed the students about the assignments to be given and the assessment criteria. Then the teacher records the results of the assessment of the assignments collected by students. In assessing the skills, the teacher also uses portfolio assessment. However, not all Chinese basic skills can be portfolioed. The results of this study are supported by research by Wolf and Ellen Stevan [7], which states that rubrics are used in assessing student products and performances so that teachers can use them in carrying out the next material learning. In line with Kulprasit's research [8], the results of the study found that students showed positive attitudes in writing rubrics, through the experience of writing rubrics with students' perspectives in positive impact assessment and directed towards formative assessment. 
Table 1. Distribution Regarding Authentic Assessment.

\begin{tabular}{|l|l|l|l|l|}
\hline \multicolumn{1}{|c|}{ No. } & \multicolumn{1}{|c|}{ Indicator } & \multicolumn{1}{c|}{ Question } & YES \\
\hline 1. & Authentic assessment & $\begin{array}{l}\text { a. Making instruments for assessing } \\
\text { attitudes (observations, and journals), } \\
\text { knowledge (written tests, oral tests and } \\
\text { assignments), and skills (performance } \\
\text { and portfolios) }\end{array}$ & $\sqrt{ }$ & \\
\cline { 3 - 5 } & & $\begin{array}{l}\text { b. Appropriateness of the assessment } \\
\text { instrument with the indicators }\end{array}$ & $\sqrt{ }$ & \\
\hline
\end{tabular}

Table 2. Regarding the Difficulties of Teachers in the Implementation of Authentic

\begin{tabular}{|c|c|c|c|c|}
\hline No. & Indicator & Question & YES & NO \\
\hline \multirow[t]{2}{*}{1.} & \multirow[t]{2}{*}{$\begin{array}{l}\text { Character and number of } \\
\text { students }\end{array}$} & $\begin{array}{l}\text { a. Having difficulty in assessing the many and different characters } \\
\text { of students in one class }\end{array}$ & $\sqrt{ }$ & \\
\hline & & b. Having difficulty in assessing spiritual and social attitudes. & & $\sqrt{ }$ \\
\hline \multirow[t]{3}{*}{2.} & \multirow[t]{3}{*}{ Time } & $\begin{array}{l}\text { a. The effectiveness of the allocation of study time determined by } \\
\text { the school }\end{array}$ & $\sqrt{ }$ & \\
\hline & & $\begin{array}{l}\text { b. The effectiveness of the teacher's learning time allocation in } \\
\text { carrying out authentic assessments }\end{array}$ & & $\sqrt{ }$ \\
\hline & & c. Accuracy of students in collecting assignments & & $\sqrt{ }$ \\
\hline \multirow[t]{2}{*}{3.} & \multirow[t]{2}{*}{ Infrastructure } & $\begin{array}{l}\text { a. Availability of facilities and infrastructure in the implementation } \\
\text { of authentic assessment }\end{array}$ & $\sqrt{ }$ & \\
\hline & & $\begin{array}{l}\text { b. Utilization of facilities and infrastructure in the implementation } \\
\text { of authentic assessment }\end{array}$ & $\sqrt{ }$ & \\
\hline
\end{tabular}

In the assessment of knowledge, the teacher used written, oral, and assignment tests. The written test is divided into two, namely multiple-choice and description. This written test is usually used during midsemester tests, end-of-semester tests and daily tests. Daily tests are carried out when one of the basic competencies has been studied to completion. However, before taking the written test, the students were informed about what would be tested, this was done to prepare before the written test was held. Therefore, the results obtained were good.

Oral tests were used by the teacherss when students make improvements, the aim is to help students understand more deeply the material that has been taught previously. For the assignment technique, the teacher usually gives assignments individually or in groups to make students better understand the material that has been studied. Assignments could be given at the time of teaching and learning carried out or at home, with a time limit that had been mutually agreed upon and assessed based on predetermined criteria.
Based on Table 2 questions 1.a, the teacher had difficulty in assessing the characteristics of many students in one class this is due to the different character of students. if the student is diligent, the tasks and questions given by the teacher when learning begins, they will be very active in answering and submitting assignments on time, but if the student is not diligent, then when learning begins, the student tends to be passive, even the assignments are not collected or done. Plus the number of students in one class.

Based on Table 2, question 1.b in assessing spiritual and social attitudes is seen when students pray, greet and tolerate friends. The aspects assessed are curiosity, earnest, confidence, creative and thoroughness. Based on Table 2, questions 2.a, the effectiveness of the time given by the affective school is 90 minutes in one subject. Meanwhile, based on Table 2, question 2.b, the teacher's learning time allocation in carrying out authentic assessments is not effective. This is because the limited time that the teacher had cannot fully reach the implementation of authentic assessment. The teacher 
only had one day for each meeting. This is because the available study time cannot reach the implementation of the assessment of all competencies completely. Competencies that are often not fully assessed are skills competencies. Often the time available is not sufficient to conduct a skill competency assessment for all students.

Based on Table 2, question 2.c Some students are still late in submitting assignments on time, this is due to the different character of students, some are diligent, some are not, but most of them collect assignments on time. Based on Table 2, question 3.a, points out that the availability of infrastructure at the start of learning will have an influence on the process of implementing an authentic assessment. The availability of facilities and infrastructure from school to support the implementation of authentic assessments for Chinese subjects at SMK Prapanca 2 Surabaya is not adequate. This is because schools do not facilitate Chinese language manuals for students and teachers, for example, the available LCDs are very limited, so if teachers need LCDs for teaching and learning facilities must alternate with other classes, because not every class has an LCD. Therefore, that it can hinder the learning process. The results of this study were supported by research conducted by Suyatmini et al [9]. The results of the study obtained that several problems faced by vocational school teachers in Surakarta in implementing the 2013 curriculum included difficulties in managing 2013 curriculum learning, problems in the learning process using a scientific approach and difficulties in the learning process with using authentic assessment. Based on Table 2, question 3.b shows that the teacher and each student already holds a manual made by the teacher in the form of a module that is adapted to the Mandarin language curriculum for SMK, that is, each student is asked to copy the module given by the teacher as a student learning guide. Therefore, that the teacher's student assignments provide the questions contained in the module.

\subsection{Utilization of authentic assessment results for Chinese subjects at SMK Prapanca 2 Surabaya}

Based on the results of the authentic evaluation of the 2013 curriculum used by the Mandarin language teacher, SMK Prapanca 2 Surabaya can be used as a grouping of students based on their individual achievements. After grouping, the teacher can determine what kind of educational procedures are suitable for the student's expertise. The teacher needs this grouping to homogenize students with the same characteristics in a class so that it is easier for teachers to carry out educational assessments. In addition, teachers can more easily carry out revisions in the education implementation plan by using authentic evaluations. Because the results of an evaluation conducted by the Mandarin teacher at the SMK Prapanca 2 Surabaya are influenced by several aspects, one of which is educational planning and is also a significant part of the teacher's duties as education administrators. The teacher tried this by holding an assessment meeting at the end of the semester by discussing the obstacles experienced throughout the evaluation process.

The results of this evaluation can be interpreted that the use of authentic evaluation results can be used as an assessment. Merta et al. [10] formulate that the purpose of education is part of the education plan so that periodic assessments are needed in order to control the achievement of educational goals. Then, it is alos need to control how teachers implement the assessment and educational goals, so that periodic assessments can be tried so that they can be identified, whether the educational goals have been achieved or not.

\section{CONCLUSION}

In conducting an authentic assessment, the teacher made an assessment instrument in the lesson plans and adjusted to the indicators. The authentic assessment carried out by the Mandarin teacher at SMK Prapanca 2 Surabaya is an assessment of cognitive, affective and psychomotor aspects. The difficulty in assessing student characteristics is due to the different character of students and a large number of students in one class. For the time allocation that the school has given is already effective. However, to be able to assess authentic assessments in one meeting is very difficult. This is because the time available is very less, so a teacher cannot assess authentic assessments in one meeting with the same amount of time given is 90 minutes in one meeting.

The infrastructure facilities at SMK Prapanca 2 Surabaya are still lacking. There are no accompanying books for students and teachers, so the teacher takes the initiative to create a Chinese language module adapted to the Chinese curriculum. Then studesnts are asked to copy the module. Not only that, LCDs in each class are also not available, so if one class requires an LCD, they must take turns. This can cause delays in learning.

However, in this authentic assessment, it is beneficial for teachers to determine students' abilities. This the teacher can more easily choose what method is most suitable for use according to students' abilities. Not only that, authentic assessment can assist teachers in evaluating the implementation plans and learning objectives that the teacher has planned, so that by conducting regular evaluations, it can be seen whether the learning objectives have been achieved or not.

\section{REFERENCES}

[1] R. A. Sani, Penilaian Autentik. Jakarta: Bumi Aksara, 2016.

[2] R. Rusman, Pembelajaran Tematik Tepadu. Jakarta: Raja Grafindo Persada, 2015. 
[3] A. Prastowo, Menyusun RencanaPelaksanaan Pembelajaran (RPP) Tematik Terpadu Implementasi Kurikulum 2013 Untuk SD/MI. Jakarta: Kencana, 2015.

[4] S. Sutama, G. A. Sandy, and D. Fuadi, "Pengelolaan Penilaian Autentik Kurikulum 2013 Mata Pelajaran Matematika di SMA," Manaj. Pendidik., vol. 12, no. 1, 2017, p. 105, doi: 10.23917/jmp.v12i1.2967.

[5] D. P. Setiaari, R. Jaenudin, and D. Koryati, "Analisis Pelaksanaan Penilaian Autentik Dalam Pembelajaran Ekonomi Di Sekolah Menengah Atas Negeri 1 Palembang," J. PROFIT Kaji. Pendidik. Ekon. dan Ilmu Ekon., vol. 6, no. 2, 2019, pp. 167175, doi: 10.36706/jp.v6i2.9060.

[6] L.J. Moleong, Metode Penelitian kualitatif, Bandung: Remaja Rosdakarya, 2021.

[7] K. Wolf and E. Stevens, "The role of rubrics in advancing and assessing student learning," J. Eff. Teach., vol. 7, no. 1, 2007, pp. 3-14, [Online]. Available:

http://works.bepress.com/cgi/viewcontent.cgi?articl $\mathrm{e}=1058 \&$ context $=$ susan_madsen\#page $=8$.

[8] W. Kulprasit, "EFL Students' Attitudes toward Authentic and Formative Assessment: The Role of Writing Rubric," Int. J. Lang. Lit. Linguist., vol. 2, no. $1, \quad$ pp. 32-37, 2016, doi: 10.18178/ij111.2016.2.1.63.

[9] S. Suyatmini, Y. Sarjono, T. Asmawati, W. Rohman "Accounting Learning Management on Curriculum 2013 Based on Lesson Study at Vocation School Surakarta” International Journal of Education, vol. 7, no. 4, 2015.

[10] I. M. E. D. Merta, I. M. Suarjana, and L. P. P. Mahadewi, "Analisis Penilaian Autentik Menurut Pembelajaran Kurikulum 2013," e-Journal PGSD Univ. Pendidik. Ganesha, vol. 3, no. 1, 2015, p. 10. 